Ann. Biol. anim. Bioch. Biophys., 1978, 18 (6), 1435-1441.

\title{
Relationship of estrous behaviour with follicular growth and sex steroid concentration in the follicular fluid in the domestic rabbit
}

par Brigitte LEFÈVRE, Monique CAILLOL

Station centrale de Physiologie animale, I. N. R. A.

78350 jouy en josas, France.

Summary. The relation between estrous behaviour, follicular growth and sex steroids concentration in follicular fluid has been studied in the young mature female rabbit.

When estrous and diestrous females are compared, it appears that the estrous animals have more large follicles (diameter $\geqslant 1.5 \mathrm{~mm}$ ), a lower rate of atresia and a higher concentration of estradiol, estrone and progesterone in follicular fluid.

\section{Introduction.}

Since the early observations of Hammond and Marshall (1925), mature female rabbits are generally considered to be in permanent estrus if they have not had recent access to a male, that is if they are not pregnant or pseudopregnant. A definition of estrus in this species is usually related to sexual behaviour : a female which submits to mating is said to be in estrus and one which does not is termed diestrus. But this notion of permanent estrus is very imprecise since the estrous period in domestic rabbits may vary from a few days to some 15 days or more (Bütfner and Wienert, 1935).

There exists a paucity of data concerning follicular growth and steroid secretion with respect to sexual behaviour. Some investigations have shown that the lifespan of the largest follicles in the ovary could be from 7 to 10 days, the period corresponding to estrus beeing from 2 to 3 days (Hill and White, 1933 ; Dworzak and Podleschka, 1934). The wild rabbit seems to have a 7 days estrous behaviour cycle in relation to this follicular growth (Myers and Poole, 1962).

The evolution of steroids in follicular fluid (Younglai, 1972) or in plasma (Hilliard and Eaton, 1971) has been studied only in female from mating through ovulation.

We have therefore attempted to study the relationship between follicular growth, steroid content of follicular fluid and the triggering of estrus behaviour. 


\section{Material and methods.}

Animals. - New Zealand virgin female rabbits 4 to 5.5 months old were housed in individual cages under $12 \mathrm{hrs}$ light $/ 24 \mathrm{hrs}$. The first experimental day, the females were placed with a buck and those refusing to mate were noted as diestrous females. One-half were killed immediately and their ovaries recovered as diestrous day-1 ovaries. The other half were put in another room under $16 \mathrm{hrs}$ light $/ 24 \mathrm{hrs}$ in order to induce estrus (Lefèvre and Moret, 1978). Twenty-four hours after transfer the females were presented to the male every day for 4 consecutive days. They were killed immediately after the first coitus or after 4 days of non-mating; the ovaries recovered were respectively estrous or diestrous day-4 ovaries.

Histological study. - The ovaries of 8 estrous females killed just after the first coitus and of 8 diestrous ones killed after 4 days of non-mating were fixed, serially cut into $10 \mu$ sections and stained with hematoxylin and eosin. All the follicles with a diameter $\geqslant 0.4 \mathrm{~mm}$ were measured and classed according to size, which was calculated from the means of two orthogonal diameters on the section where the nucleus of the oocyte was present. Follicles $\geqslant 1 \mathrm{~mm}$ were classed as healthy or atretic by histological criteria (presence or absence of pyknotic nuclei in the granulosa cells). In the rabbit according to Asami (1920) and Pincus and Enzmann (1937), atresia in large follicles $(\geqslant 0.3 \mathrm{~mm})$ is characterized by degeneration and pyknotic nuclei of the granulosa cells.

Steroid radioimmunoassay in follicular fluid. - Immediately after the animals were killed, the ovaries were recovered and the follicular fluid aspirated with a 26 gauge needle and syringe. All ovarian follicles $\geqslant 0.5 \mathrm{~mm}$ in diameter were punctured and the fluid was weighed and stored immediately at $-20^{\circ} \mathrm{C}$. Fluids resulting from individual females were assayed separatly.

Three experimental groups of females were examined. Estradiol-17 $\beta$ (E2 17 $\beta$ ) was assayed in the first group composed of 10 estrous females, 9 diestrous day- 1 and 4 diestrous day- 4 animals. The second group consisted of 7 estrous and 7 diestrous day-1 females and was used for estrone (E1) determination. There were 13 estrous females and 14 diestrous day-1 animals in the third group which was used for progesterone (P) determination.

Chemicals. - Non-radioactive steroids were obtained from Steraloids. Progesterone 1-2-6-7-(n)- $\mathrm{H}^{3}$, estradiol $17 \beta-2-4-6-7(n)-\mathrm{H}^{3}$ and estrone 2-4-6-7(n)- $\mathrm{H}^{3}$ (80$100 \mathrm{ci} / \mathrm{mmol}$ ) were obtained from the Radiochemical Center Amersham. Merck analytical grade solvents were used without re-distillation.

Estradiol-173. - The thawed follicular fluid was diluted in $1.5 \mathrm{ml}$ of phosphate buffer, $\mathrm{pH} 7.25$. $1000 \mathrm{cpm}$ of radioactive $E_{2} 17 \beta$ were added for calculation of recovery and extraction was performed using $10 \mathrm{ml}$ of methylene chloride. Recovery after extraction varied from 85 to 90 p. 100.

The antibody used was obtained from rabbits immunized against estradiol $17 \beta-$ 6-carboxymethyl-oxime conjugated to bovine serum albumin; antiserum dilution was $1 / 20000$. Bound and free hormones were separated by double precipitation using 
rabbit $y$ globulin ovine antiserum. We studied the following reliability criteria (table 1): Specificity. - The percentages of cross-reaction were as follows :

with $E_{1} 10$ p. 100 ; with $16-$ ceto- $E_{2} 4.5$ p. 100 ; with $16-e$ i- $E_{3} 1.10$ p. 100 ; with $E_{2} 17 \alpha$ and $E_{3}<1$ p. 100 .

Accuracy. - Known amounts of $E_{2} 17 \beta$ were added to follicular fluid samples. Agreement between the quantity added and that recovered was good.

Serial dilutions. - Dilutions of the same sample showed good linearity between the assayed volume and the amount of steroid recovered.

\section{TABLE 1}

Radioimmunoassay of steroids in follicular fluid : reliability criteria

\begin{tabular}{lccccc}
\hline $\begin{array}{c}\text { Steroid } \\
\text { assayed }\end{array}$ & $\begin{array}{c}\text { Sensitivity } \\
\text { Standard } \\
\text { curve }\end{array}$ & Assay & Accuracy & $\begin{array}{c}\text { Aspecific } \\
\text { interference }\end{array}$ & Blank values \\
\hline $\mathrm{E}_{2} 17 \beta \ldots$ & $2-5 \mathrm{pg}$ & $6-15 \mathrm{pg}$ & $\begin{array}{l}\mathrm{b}=0.9 * \\
\mathrm{r}=0.99^{* *}\end{array}$ & None & $\begin{array}{c}\text { Below assay } \\
\text { sensitivity }\end{array}$ \\
\hline $\mathrm{E}_{1} \ldots \ldots$ & $2-5 \mathrm{pg} \quad 6-15 \mathrm{pg}$ & $\begin{array}{l}\mathrm{b}=0.96^{*} \\
\mathrm{r}=0.99^{* *}\end{array}$ & None & $\begin{array}{c}\text { Below assay } \\
\text { sensitivity }\end{array}$ \\
\hline $\mathrm{P} \ldots \ldots$ & $25-50 \mathrm{pg}$ & $1 \mathrm{ng}$ & $\begin{array}{l}\mathrm{b}=1.12^{*} \\
\mathrm{r}=0.99^{* *}\end{array}$ & None & $\begin{array}{c}\text { Below assay } \\
\text { sensitivity }\end{array}$ \\
\hline
\end{tabular}

${ }^{*} \mathrm{~b}=$ slope of the regression curve ; ${ }^{*} \mathrm{r}=$ correlation coefficient.

Estrone. - The thawed follicular fluid was diluted in $1 \mathrm{ml}$ of phosphate buffer and extracted with ethyl acetate/cyclohexane (50/50, v/v) after addition of $1000 \mathrm{cpm}$ of labelled $E_{1}$. The antibody used was raised in rabbits against estrone 17-paraaminobenzoic-BSA; it was used at a dilution of $1 / 3000$. The specificity of this antibody was determined and the percentages of cross-reaction with other estrogens were :

with $E_{2} 17 \beta 20$ p. 100 ; with $E_{2} 17 \alpha 20$ p. 100 ; with $E_{3} 13$ p. 100 ; with 16-ceto- $E_{2}$ and 16-epi- $E_{3}<1$ p. 100.

This antibody was relatively unspecific. So a purification of estrone on microcolumns of celite was performed.

Recovery after extraction and chromatography varied between 72 and 95 p. 100. The same reliability criteria as for $E_{2} 17 \beta$ were studied; the results are shown in table 1.

Progesterone. - The thawed follicular fluid was diluted in $1 \mathrm{ml}$ of phosphate buffer and extracted with $10 \mathrm{ml}$ of $n$-hexane after addition of $1000 \mathrm{cpm}$ of radioactive $P$; recovery after extraction varied between 60 and 93 p. 100 . The antibody used was raised in rabbits against progesterone- 11 hemi-succinate-BSA; it was used at a dilution of $1 / 6000$. The specificity of this antibody was studied and the following percentages of cross-reaction were found : 
with $5 x$-pregnane-3-20 dione 7.5 p. 100 ; with deoxycorticosterone 7.5 p. 100 ;

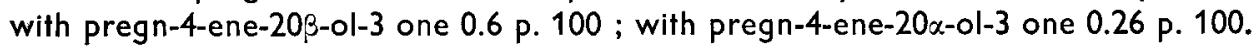

The same reliability criteria as for $E_{2} 17 \beta$ and $E_{1}$ were studied (table 1 ).

Statistics. - The standard error of the mean (SEM) was calculated assuming normal distribution. Statistical significance was estimated by Student's $\dagger$ test. Significance was postulated for $P \leqslant 0.05$.

\section{Results.}

Follicular growth. - No significant difference was found in the number of follicles 0.4 to $1.5 \mathrm{~mm}$ in diameter between estrous and diestrous females.

In contrast, the mean number of follicles of 1.5 to $1.8 \mathrm{~mm}$ was significantly higher in estrous than in diestrous females; follicles with a diameter $>1.8 \mathrm{~mm}$ were only present in the estrous females (table 2).

\section{TABLE 2}

Number of healthy and atretic follicles in estrous and diestrous day- 4 females

\begin{tabular}{|c|c|c|c|c|c|c|}
\hline \multirow{2}{*}{$\begin{array}{l}\text { Diameter } \\
(\mathrm{mm})\end{array}$} & \multicolumn{3}{|c|}{$\begin{array}{l}\text { Estrous females } \\
\qquad n=8\end{array}$} & \multicolumn{3}{|c|}{$\begin{array}{l}\text { Diestrous Day-4 females } \\
\qquad n=8\end{array}$} \\
\hline & $\begin{array}{l}\text { Total number } \\
\text { of follicles } \\
\mathrm{m} \pm \mathrm{SEM}\end{array}$ & $\begin{array}{l}\text { Healthy } \\
\text { follicles } \\
m \pm S E M\end{array}$ & $\begin{array}{l}\text { Atresia } \\
\text { (p. 100) }\end{array}$ & $\begin{array}{c}\text { Total number } \\
\text { of follicles } \\
\mathrm{m} \pm \mathrm{SEM}\end{array}$ & $\begin{array}{l}\text { Healthy } \\
\text { follicles } \\
\mathrm{m} \pm \text { SEM }\end{array}$ & $\begin{array}{l}\text { Atresia } \\
\text { (p. 100) }\end{array}$ \\
\hline $\begin{array}{l}0.4-0.9 \\
0.9-1.2 \\
1.2-1.5 \\
1.5-1.8 \\
1.8-2.1\end{array}$ & $\begin{array}{r}137.5 \pm 8.3 \\
5.9 \pm 1.2 \\
3.3 \pm 0.6 \\
2.9 \pm 0.9 \\
0.4\end{array}$ & $\begin{array}{l}3.9 \pm 0.8 \\
2.7 \pm 0.5 \\
2.4 \pm 0.8 \\
0.4\end{array}$ & $\begin{array}{r}\overrightarrow{34} \\
15 \\
17 \\
0\end{array}$ & $\begin{array}{c}126.5 \pm 18.5 \\
7.1 \pm 2.4 \\
3.8 \pm 1.1 \\
0.4 \pm 0.2 \\
0\end{array}$ & $\begin{array}{l}4.3 \pm 1.4 \\
3.3 \pm 1.1 \\
0.3 \pm 0.2 \\
\frac{0}{0}\end{array}$ & $\begin{array}{r}-\overline{40} \\
13 \\
33 \\
0\end{array}$ \\
\hline
\end{tabular}

Follicles of 0.4 to $0.9 \mathrm{~mm}$ were not ciassed as healthy or atretic. In those of 0.9 to $1.2 \mathrm{~mm}$, the percentage of atresia is the same for estrous (4 p. 100) and diestrous (6 p. 100) females. Atresia is more important in the largest follicles $(1.5$ to $1.8 \mathrm{~mm}$ ) of diestrous females than in those of estrous animals (table 2). Thus, the mean number of large healthy follicles was significantly higher for the estrous $(2.4 \pm 0.8)$ than for the diestrous $(0.3 \pm 0.2)$ females.

Steroid levels in the follicular fluid (table 3 and fig. 1). - The mean number of punctured follicles was the same in the two groups of females but follicular fluid mean weight was significantly higher in the estrous than in the diestrous females.

$E_{2} 17 \beta$ levels were significantly more elevated in follicular fluids of estrous rabbits $(79.5+13.1 \mathrm{pg} / \mathrm{mg}$ follicular fluid) than in those of diestrous day-1 females (14.5 $\pm 4.8 \mathrm{pg} / \mathrm{mg}$ follicular fluid). The same result was found for $E_{1}: 148.8 \pm 30.3$ $\mathrm{pg} / \mathrm{mg}$ follicular fluid for estrous females, $18.9 \pm 7.2 \mathrm{pg} / \mathrm{mg}$ follicular fluid for diestrous animals. Four females which had refused to mate during 4 consecutive days 
(diestrous day 4 animals) showed significantly different mean $E_{2} 17 \beta$ values from those of the 2 other groups (32.8 $\pm 15.9 \mathrm{pg} / \mathrm{mg}$ follicular fluid), but individual variation was very wide $(6-75 \mathrm{pg} / \mathrm{mg}$ follicular fluid).

TABLE 3

Follicular fluid steroid content in estrous and diestrous females

I. - Estradiol-17 $\beta$

\begin{tabular}{lccccrr}
\hline $\begin{array}{c}\text { Sexual } \\
\text { state }\end{array}$ & $\begin{array}{c}\text { Number } \\
\text { of } \\
\text { females }\end{array}$ & $\begin{array}{c}\text { Mean number of } \\
\text { punctured follicles } \\
\text { per female }\end{array}$ & $\begin{array}{c}\text { Mean weight of } \\
\text { follicular fluid } \\
\text { per female (mg) }\end{array}$ & $\begin{array}{c}\text { Steroid } \\
\text { pg/mg folli- } \\
\text { cular fluid }\end{array}$ & $\begin{array}{r}\text { Steroid } \\
\text { pg/follicle }\end{array}$ \\
\hline Estrus . . . . . & 10 & $10.4 \pm 0.6$ & $8.5 \pm 0.9$ & $79.5 \pm 13.1$ & $73.8 \pm 15.5$ \\
Diestrus day 1 & 9 & $9.9 \pm 0.6$ & $6.5 \pm 1.1$ & $14.5 \pm 2.8$ & $8.0 \pm 2.7$ \\
Diestrus day 4 & 4 & $7.8 \pm 0.9$ & $7.2 \pm 2.2$ & $32.8 \pm 15.9$ & $34.6 \pm 21.3$ \\
\hline
\end{tabular}

\section{II. - Estrone}

\begin{tabular}{|c|c|c|c|c|c|c|}
\hline $\begin{array}{l}\text { Estrus } \ldots \ldots \\
\text { Diestrus day } 1\end{array}$ & $\begin{array}{l}7 \\
7\end{array}$ & $\begin{array}{r}10.6 \pm 1.3 \\
9.6 \pm 0.5\end{array}$ & $\begin{array}{l}8.0 \pm 1.9 \\
4.9 \pm 1.1\end{array}$ & $\begin{array}{r}147.8 \pm \\
18.9 \pm\end{array}$ & $\begin{array}{r}30.3 \\
7.2\end{array}$ & $\begin{array}{r}117.7 \pm \\
11.2 \pm\end{array}$ \\
\hline
\end{tabular}

III. - Progesterone

$\begin{array}{lrrrrr}\text { Estrus . . . } & 13 & 10.6 \pm 0.5 & 11.2 \pm 1.5 & 1104.5 \pm 233.9 & 1207.0 \pm 312.9 \\ \text { Diestrus day } 1 & 14 & 10.3 \pm 0.6 & 7.4 \pm 1.0 & 674.5 \pm 192.4 & 376.1 \pm 64.5\end{array}$

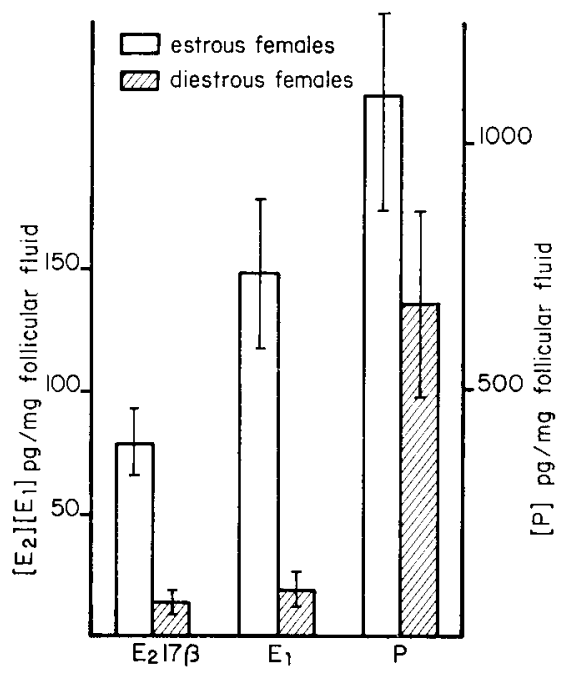

FIG. 1. - Steroid content of follicular fluid in estrous and diestrous day-1 females.

Vertical bars represent standard error of the mean (SEM). 
The mean levels of progesterone were higher in the estrous females (1 $104.5 \pm 233.9 \mathrm{pg} / \mathrm{mg}$ follicular fluid) than in the others $(674.5 \pm 192.4 \mathrm{pg} / \mathrm{mg}$ follicular fluid), but the difference was only highly significant for results given in $\mathrm{pg} / \mathrm{fol}$ licle $(1207 \pm 312.9 \mathrm{pg} /$ follicle versus $376.1 \pm 64.5 \mathrm{pg} /$ follicle $)$.

\section{Discussion.}

When estrous and diestrous females are compared, it appears that the estrous animals have more large follicles (diameter $\geqslant 1.5 \mathrm{~mm}$ ), a lower rate of atresia, and $a$ higher concentration of $E_{2}, E_{1}$ and $P$ in the follicular fluid. The difference between estrous and diestrous females is only found in the largest follicle group in this study. The presence of these large healthy follicles seems to be related to a higher weight of follicular fluid and stronger steroid concentrations.

But the mean number of eggs generally recovered in the genital tract of a rabbit after ovulation ranges from 8 to 12 ; this number is close to the mean number of follicles found in the classes 0.9 to $1.5 \mathrm{~mm}$ in diameter which is not significantly different between the two groups of females.

These questions are to be solved: what is the role of these large follicles ? Are they responsible in some way for the maturation of the follicles 1.0 to $1.5 \mathrm{~mm}$. in diameter and which are the ovulating follicles?

In the histological study, diestrous ovaries were only recovered from females refusing to mate during 4 consecutive days; in these diestrous day- 4 animals, the concentration of $E_{2}$ in the follicular fluid was intermediary between the estrous and the diestrous day- 1 groups, and the $E_{2}$ values ranged from 6 to $75 \mathrm{pg} / \mathrm{mg}$ of follicular fluid. The large individual variation can be explained by the fact that some of the females from this group could be ready to mate the next day while the others were still in deep diestrous. There may be a greater difference in follicular growth between estrous and diestrous day- 1 females.

Follicular steroid concentrations measured here are very similar to values obtained by other authors. Younglai (1972) and Patwardhan and Lanthier (1976) gave progesterone values of 700 to $900 \mathrm{pg} / \mathrm{mg}$ follicular fluid ; Patwardhan and Lanthier found an estradiol level of $80 \pm 33 \mathrm{pg} / \mathrm{mg}$ follicular fluid and an estrone level of $65 \pm 20$ $\mathrm{pg} / \mathrm{mg}$ follicular fluid in follicles of diameter $\geqslant 1 \mathrm{~mm}$ of sexually mature females. The content of total estrogens in follicles of diameter $\geqslant 0.7 \mathrm{~mm}$ is $60 \pm 5 \mathrm{pg} / \mathrm{mg}$ follicular fluid for Younglai (1972) and $77 \pm 34 \mathrm{pg} /$ follicle for Nicosia, Evangelista and Batta (1975).

Our values for the three steroids assayed are lower for diestrous females and higher for estrous ones than those given in the literature. This can be explained by the fact that the authors have used females killed before mating, without taking into account their sexual state (estrous or diestrous).

Thus, in the rabbit the transition from diestrus to estrus corresponds to an increase in follicle size and in steroid concentration in the follicular fluid. Mating induces further increases in the steroid concentration (Patwardhan and Lanthier, 1976) followed by a decrease to basal levels at the time of ovulation. 
Aknowledgements. - The authors wish to thank Dr M. Terqui for the gift of $E_{2} 17 \beta, E_{1}$ and $\mathrm{P}$ antisera and Régine Monnerie for her technical assistance.

Résumé. La relation entre l'apparition du comportement d'œstrus, la croissance folliculaire ef l'évolution des concentrations en stéroïdes sexuels dans le liquide folliculaire ont été étudiées chez la lapine vierge pubère.

Les femelles en cstrus diffèrent des femelles en diœstrus par :

- un plus grand nombre de gros follicules (diamètre $\geqslant 1,5 \mathrm{~mm}$ ) et un taux d'atrésie plus faible ;

- une concentration en œstradiol, œstrone ef progestérone dans le liquide folliculaire plus élevée.

\section{Références}

ASAMI G., 1920. Observations on the follicular atresia in the rabbit ovary. Anat. Rec., 18, 323-343.

BÜTTNER W., WIENERT K., 1935 . Dauerbrunst und Follikelpersistenz (Experimentelle Untersuchungen an Kaninchen), Arch. Gynäkol., 159, 64-83.

DWORZAK H., PODLESCHKA K., 1934. Über die Anheilungs - und Wachstumsvorgänge autoplastisch in die Augenvorderkammer des Kaninchens verpflanzter Ovarien, Uterus und Tubenstücke. Z. Geburtshilfe, 108, 354-375.

HAMMOND J., MARSHALL F., 1925. Reproduction in the rabbit. III - The female reproduction phases, 25-54 Oliver and Boyd, Edinburg.

HILL M., WHITE W., 1933. The growth and regression of follicles in the cestrous rabbit. J. Physiol., 80, 174-178.

HILLIARD J., EATON L. W. M., 1971. Estradiol 17 $\beta$, progesterone and $20 \alpha$-hydroxy-pregn-4-en3-one in rabbit ovarian venous plasma. II - From mating through implantation. Endocrinology, 89, 522-527.

LEFÈVRE B., MORET B., 1978. Influence d'une modification brutale de l'environnement sur l'apparition de l'œstrus chez la lapine nullipare. Ann. Biol. anim. Bioch. Biophys., 18, 695-698.

MYERS K., POOLE W. E., 1962. Oestrous cycles in the rabbit, Oryctolagus cuniculus. Nature, 195, 358-359.

NICOSIA S. V., EVANGELISTA I., BATTA S. K., 1975. Rabbit ovarian follicles. 1 - Isolation technique and characterization at different stages of development. Biol. Reprod., 13, 423-447.

PATWARDHAN V. V., LANTHIER A., 1976. Effect of an ovulatory dose of luteinizing hormone on the concentration of œstrone, œstradiol and progesterone in the rabbit ovarian follicle. Acta endocrinol., 82, 792-800.

PINCUS G., ENZMANN E. V., 1937. The growth, maturation and atresia of ovarian eggs in the rabbit. J. Morph., 61, 351-382.

YOUNGLAI E. V., 1972. Effects of mating on follicular fluid steroids in the rabbit. J. Reprod. Fert., 30, 157-159. 